\title{
Legislative Best Practices for Securing Women's Rights to Community Lands
}

This brief highlights key attributes of national constitutions, laws, and regulations that play a fundamental role in protecting indigenous and rural women's rights to community forests and other community lands.' These legislative best practices were derived from a 2017 analysis of over 400 national laws and regulations, Power and Potential, which evaluates the extent to which women's rights to community forests $^{a}$ are recognized by national law in 30 low- and middle-income countries (LMICS) across Africa,
CEDAW Art. 2: "State Parties ... agree to pursue by all appropriate means and without delay a policy of eliminating discrimination against women and, to this end, undertake: ... to modify or abolish existing laws, regulations, customs and practices which constitute discrimination against women." Asia, and Latin America. Most of the legislative attributes presented contributed to "full credit"b scores with respect to the eight legal entitlements assessed under Power and Potential's methodology. These legal entitlements examine constitutional equal protection, general affirmations of women's property rights, the overarching recognition of inheritance rights for all women throughout a country, and the following community-level entitlements that are specific to indigenous and local communities: membership, inheritance, voting, leadership, and dispute resolution. Other recommendations featured in this brief are prescriptions for avoiding the most significant legislative failures illuminated by the same 2017 study.

The identification of legislative best practices concerning the legal recognition and protection of women's rights to community lands is a critical step toward developing laws that both enable and support tenure security. When laws recognizing indigenous and rural women's tenure rights exist, women can utilize these laws to defend their legal entitlements and those of their larger community, and to shape community practices in a manner that respects the equal tenure rights of both women and men. Legal recognition of women's tenure rights is also crucial to the realization of sustainable development objectives, including:

Economic security, food security, and cultural heritage: Tenure security enables women to consistently fulfill pivotal responsibilities regarding the maintenance of community lands and natural resources, and these contributions play a major role in combating rural poverty and maintaining community livelihoods. Women are daily managers of community lands, and are commonly engaged in compensated and uncompensated land-based labor (such as labor related to subsistence and commercial cultivation, and the gathering of forest products to satisfy household needs for food, energy, fodder for livestock, clothing, traditional medicines, and other culturally significant items) that is essential for their food security, economic viability, and cultural/religious heritage, as well as

\footnotetext{
a Legislative data underlying Power and Potential can be used to identify legislative best practices with respect to laws regulating both forested and non-forested community lands because this data is comprised of national-level laws and regulations governing land, forests, rural development, civil rights, succession, and marriage.

b Notably, "full credit" assessments under the methodology employed in Power and Potential are consistent with adequate recognition of the core legal protections mandated by the Convention on the Elimination of All Forms of Discrimination against Women (CEDAW) and its general recommendations as central to the eradication of discrimination against rural women regarding land and community participation.
} 
those of their households and larger communities.

Health, well-being, and education: It is now widely recognized that secure land rights for women result in improvements in the health and education of both women and their wider communities. In contrast, indigenous and rural women who lack reliable, enforceable rights to the community lands they depend on for survival are especially vulnerable to a host of injustices. They may face limited choices regarding marriage and consensual unions, including in key decisions that may protect them from HIV/AIDS. These restraints on women's personal agency reduce their well-being and negatively affect the livelihoods of women and their families.iii

Mitigating and adapting to climate change: Women within indigenous and local communities often possess distinct sets of knowledge regarding forest resources, and they use, conserve, and value resources differently than men. Consequently, women's decisions regarding resource use have a significant bearing on the maintenance of biodiversity and the reduction of forest carbon emissions. Furthermore, indigenous and rural women are often less able to adapt to_and are differently and disproportionately affected by_community-level shocks related to climate change. ${ }^{\text {iv }}$

\section{Key Findings from Power and Potential}

Of the 30 countries analyzed, all have ratified CEDAW; all but two were found to recognize gender equality or prohibit gender-based discrimination in their constitutions; and over half have statutory laws that generally affirm women's property rights. Yet, "less than one-third of the 30 LMICs analyzed legally mandate that all daughters, widows, and unmarried women in consensual unions have equal rights to inherit alongside their male counterparts." ${ }^{\circ}$

Furthermore, of the 80 community-based tenure

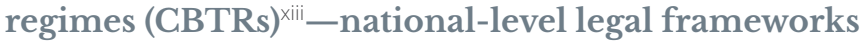
that recognize community-based tenure systemsidentified within the 30 analyzed countries, "adequate gender-sensitive provisions exist for only 3 percent of CBTRs in regard to women's voting rights, 5 percent in regard to leadership, 10 percent in regard to inheritance, 18 percent in regard to dispute resolution, and 29 percent regarding membership." xii

Crucially, Power and Potential also finds that "the legal advancement of women and of their communities can, and often do, go hand in hand." "xiii Legal frameworks that provide avenues for communities to own forests, and those that are created with the express purpose of acknowledging community-based rights, provide the greatest protections for women's rights.
Indigenous Peoples and local communities customarily use and manage over 50 percent of global land area, ${ }^{\vee}$ and the wealth of positive outcomes derived from securing women's tenure rights throughout these vast territories is well-established. Yet, Power and Potential demonstrates that existing legal frameworks regulating community forests are consistently "riddled with weak legal protections, crippling legal omissions, and discriminatory inheritance provisions that fail to protect the [tenure] rights of indigenous and rural women."vi Laws that most closely regulate women's interactions with community forests were found to be "markedly weaker than constitutional protections for women and the provisions enshrined in [The Convention on the Elimination of All Forms of Discrimination against Women (CEDAW)]." "vii This same report highlights a strong association between advancements in the legal recognition of Indigenous Peoples' 
and local communities' tenure rights and the formal tenure rights of women community members, viii although this positive finding is belied by the fact that only 10 percent of the world's lands are legally owned by indigenous and local communities. ${ }^{\text {x }}$

For indigenous and rural women, injustices confronting their communities are compounded by the fact that their specific rights to community lands are often the least protected by governments' formal laws. This lack of legal protection leaves women especially vulnerable to discriminatory community practices and the actions of powerful elites and companies involved in land-based investments. .xi Without significant genderresponsive legal reforms, efforts to secure indigenous and rural women's tenure rights and eliminate gender-based discrimination —in alignment with CEDAW, the Sustainable Development Goals (SDGs), and the Voluntary Guidelines on the Responsible Governance of Tenure of Land, Fisheries, and Forests in the Context of National Food Security (VGGT)—will remain largely unrealized.

\section{Guidance on the Purpose and Use of this Brief}

In an effort to support national governments' formal recognition of indigenous and rural women's tenure rights around the world, this brief identifies legislative elements found within the national laws of the 30 countries analyzed in Power and Potential that fortify women's rights to community forests within national constitutions and laws governing land, forests, rural development, succession, marriage, and other related matters. It aims to provide globally informed guidance to national law and policy makers with respect to legislative reforms, and to support the advocacy and information needs of indigenous and rural women residing in rural areas, community leaders, civil society organizations, researchers, and governmental agencies at different levels.

Before considering the recommendations presented, it is important to recognize the purpose and limitations of this tool. This tool does not purport to be all-inclusive-other legal provisions not featured in this analysis may prove useful or even essential to the protection of women's tenure rights in particular national contexts. Most importantly, the following broad principles of legislative reform should be understood before any of the recommendations presented are considered:

1. Reforms must be comprehensive: To adequately protect indigenous and rural women's tenure rights, reforms of national legislation and regulatory frameworks need to be harmonized across all relevant genres of law (land, forest, succession, and family laws) and be applied horizontally across all regimes within plural legal frameworks. xiv

\section{Reforms must resonate with existing customary norms and laws that respect women's equal tenure rights, ${ }^{c}$ and be led by the gender-sensitive objectives of community members}

\footnotetext{
" RRI regards the recognition and realization of women's "equal" rights to tenure as a fundamental component of women's inherent dignity and deserved justice that is necessary under international human rights law. Such recognition is a tool that indigenous and rural women can use to transform their communities in a just and gender-equal manner, and to eliminate gender-based discrimination at all levels. However, RRI's advocacy for women's "equal" rights to tenure does not counter or preclude the following assertions: 1) In some circumstances, justice may require the unequal distribution of resources in favor of particularly vulnerable persons (including women), in order to promote overall equality within communities and larger societies; and 2) Due to a number of context-specific factors, some indigenous and rural women may freely choose not to assume the same roles, responsibilities, or legal entitlements as men in their communities, despite the fact that women's equal rights to tenure are recognized by formal law and that they have equal, substantive opportunities to realize such arrangements through community-based decision making processes and negotiations at a household level. Such women may support tenure arrangements that they consider just, despite the fact that these arrangements may not be strictly "gender-equal" in all respects.
} 
rightsandresources.org

and local advocates: The utilization of legislative best practices does not eliminate law- and policymakers' fundamental responsibility to craft legislation that is informed by the voices of Indigenous Peoples and local communities, existing customary laws/practices, and the broader context within which they operate. Even the most comprehensive legal reforms will not be successful if they do not build on and strengthen community norms and customary laws that respect women's rights to access, use, and govern land and natural resources at a community level, as few (if any) communities rely solely on state-issued laws to define their relationship with community lands. Consequently, the first step in developing legislation impacting community-based tenure rights is to effectively consult with communities and ensure clear measures are in place to respect the perspectives and concerns of both women and men community-members who would be subject to the prospective legislation. In particular, indigenous and rural women advocates should play a leading role in determining the content of legal provisions concerning community lands.

3. Reforming and implementing legislation on community

lands is an ongoing process: Finally, legislative reforms are necessary but insufficient to address the many "obstacles to tenure security facing women in indigenous and local communities." ${ }^{\prime \prime v}$ Indeed, the realization of communitybased tenure rights is also dependent on social, economic, and political factors that may require more sustained interventions. Reforming and implementing legislation concerning community lands and women's rights should therefore be regarded as an ongoing and participatory process requiring close collaboration between law-makers, government institutions, communities, indigenous and rural women, and civil society organizations.

\section{Legislative Best Practices to Secure the Tenure Rights of Indigenous and Rural Women}

\section{A. National Constitutions}

1. Non-discrimination and equal protection regarding gender: Prohibit gender-based discrimination, in addition to guaranteeing equal protection under the law to both men and women.

2. Prohibit discrimination against children: Prohibit discrimination against all children, regardless of sex, and guarantee the equal protection of all children under the law.

3. Recognize customary laws/practices to the extent that they comply with the constitution: Recognize Indigenous Peoples' and local communities' customary practices, laws, and dispute resolution forums within the framework of formal law, to the extent that such customary laws, practices, and dispute resolution forums adhere to the constitution. ${ }^{d}$

4. Do not provide exemptions for constitutional compliance: Constitutional provisions should not

\footnotetext{
'Where religious laws and courts are constitutionally recognized, these laws and dispute resolution forums should also be required to comport with the provisions of the constitution.
} 
exempt individuals, groups, or institutions engaged in the implementation of customary or religious practices/laws/dispute resolution processes from complying with the provisions of the national constitution.

5. Self-executing human rights treaties: Pass constitutional provisions that make all international human rights treaties ratified by the national government-including CEDAW, ILO Convention No. 169, and the UN Convention on the Rights of the Child - "self-executing," such that they are considered to be an enforceable component of national law.

6. General affirmation of women's property rights: Affirm and guarantee all women's property rights, explicitly stating that such rights are not to be contingent on marital status.

7. Equality within family and marriage: Recognize equal rights between partners in marriages and consensual unions, as well between the children born within or adopted under such unions.

8. Guarantee inheritance rights: Recognize the rights

of all adults and children to inheritance, regardless of marital status or gender, and require the legislature to establish or amend succession laws on this basis.

9. Affirm women's equal legal capacity: Affirm that men and women have equal legal capacity, including an equal right to negotiate and execute contractual agreements, and to appear freely before a court.
CEDAW Art. 14(2): "States Parties shall take all appropriate measures to eliminate discrimination against women in rural areas in order to ensure, on a basis of equality of men and women, that they participate in and benefit from rural development and, in particular, shall ensure to such women the right:... (f) To participate in all community activities."

10. Affirm economic rights related to property, rural land, and natural resources: Affirm and guarantee all women's and men's equal rights to acquire, own, control (including management and administration), derive economic benefits from, and otherwise use property, regardless of marital status. Acknowledge that women and men are to be equal beneficiaries of agrarian reforms, and that deeds may be granted in both women's and men's names, as provided by law.

\section{B. Laws Regulating Community Lands and Forests ${ }^{x \mathrm{i}}$}

1. Prohibit gender-based discrimination with respect to land and forests: Prohibit direct and indirect discrimination with respect to all dealings related to land and forests, including discrimination based on gender or marital status.

2. Render discriminatory customary practices void: Recognize the validity of Indigenous Peoples' and local communities' customary laws, practices, and courts to the extent that they do not violate any provision of the Constitution, and/or women's, children's, or other vulnerable person's rights to access, use, and make decisions about customary/community lands.

3. General affirmation of women's land, forest, and property rights: Affirm and guarantee all women's and men's equal rights to land, forest, natural resources, and other property; acknowledge women's and men's equal rights to acquire, use, and benefit from land and natural resources. Recognize that 
rightsandresources.org

community lands, natural resources, and accrued benefits from these resources are to be used, managed, and shared on an equitable basis.

4. Gender-inclusive land allocation, titling, and certification processes, including women-headed households: Recognize that land titles, deeds, and certificates may be issued to both men and women regardless of marital status; guarantee women access to and participation in land allocation and titling programs, and require the full names of all spouses or domestic partners to be on all certificates issued at a household level. Consider passing provisions prioritizing the allocation of land and natural resources to women, with particular preference for women-headed households.

5. Recognize women's right to economic empowerment: Recognize women's rights to access credit and establish businesses associated with the management of their land and natural resources; specifically recognize indigenous and rural women's rights to access credit and form enterprises related to community lands and natural resources, either individually or through women's cooperatives.

6. Recognize women's community-level membership rights: Define "members" of indigenous and local communities to explicitly include women and girls, regardless of marital status. Do not define community membership at the level of rural "households," "families," or "household heads." Explicitly safeguard indigenous and rural women's land rights such that women retain rights to control, access, and use community lands even when their socioeconomic status changes due to marriage, divorce, the assumption or dissolution of a consensual union, the death of a husband or unmarried partner, or upon the death of a parent.

7. Recognize women's equal inheritance rights at a community-level: Within all legislation establishing community-based tenure regimes, recognize the inheritance rights of widows, women in consensual unions, and daughters at a level equal to their respective male counterparts.

8. Right to substantively participate in community-based decision-making processes: Where laws apply to communities that employ democratic decision-making processes, specify that all adult women have the right to participate in general assemblies. Require that a quorum of women-a minimum number of women voters-be present for a vote to be cast. Where laws apply to communities whose customary decision-making processes require that all adult members reach consensus, recognize all women's right to participate in these community-level assemblies.

a. Recognize women's rights to participate in all community land negotiation, acquisition, and redistribution processes: Specify that the governance rights designated above include women's participation in all community land negotiation, acquisition, and redistribution processes conducted with external actors.

9. Recognize women's rights to hold positions within community-level leadership and dispute resolution bodies: Where community leadership and dispute resolution bodies employ democratic decisionmaking processes, require that a quota of women hold seats in community-level executive and dispute resolution bodies, and that a quorum of women members be present in order for the body to preside over a matter or exercise its decision-making authority.

10. Recognize women's right to bring land/forest disputes before community-level forums and other forums: Recognize community-level dispute resolution forums and women community members' 
CEDAW Article 16: "State Parties shall take all appropriate measures to eliminate discrimination against women in all matters relating to marriage and family relations and... shall ensure... (h) The same rights for both spouses in respect of the ownership, acquisition, management, administration, enjoyment and disposition of property..."

VGGT 4.6: "States should remove and prohibit all forms of discrimination related to tenure rights, including those resulting from change of marital status, lack of legal capacity, and lack of access to economic resources. In particular, States should ensure equal tenure rights for women and men, including the right to inherit and bequeath these rights. ..." rights to bring land disputes before such forums. Explicitly state that all decisions issued by communitylevel dispute resolution bodies that are discriminatory, in violation of any national law, or in contradiction with the Constitution are void, and that courts are to safeguard the interests of women, children, and other vulnerable persons. Where customary dispute resolution forums are part of the formal judicial structure, establish optout provisions permitting women and men to move a dispute from a customary forum to the formal judiciary system if they are dissatisfied with a community-based ruling.

\section{Civil codes, family codes, and laws on succession, marriage, and domestic violence}

\section{Recognize women's equal civil, familial, and}

economic rights: Affirm that men and women have equal civil rights and rights with respect to family and social life, regardless of their gender or marital status. Recognize equal rights between spouses and between partners in consensual unions, both during the union and upon its conclusion or dissolution.

2. Equal protection for girls: Acknowledge that all children are equal before the law, regardless of sex.

3. Prohibit domestic violence, including economic violence, against all women: Prohibit domestic violence against all women and menincluding unmarried women and men in consensual unions-and legally define it to include economic forms of violence/abuse related to property.

4. Recognize women's legal capacity: Affirm that men and women have equal legal capacity, including an equal right to contract, administer the estate of a deceased spouse or domestic partner, and appear freely before a court.

5. Recognize women's equal property rights: Recognize that married and unmarried women, as well as married and unmarried men, have equal rights regarding property and its acquisition, ownership, use, management, enjoyment and disposition. Recognize equal rights between men and women to contract and to carry on any business related to property.

6. Spousal consent required to dispose of marital/jointly held, used, or possessed property: Recognize spouses' equal right to marital and joint property, as well as property jointly used or possessed; similarly, recognize unmarried partners' equal rights to jointly held, used, or possessed property. Require the consent of both spouses/unmarried partners in order for any marital/jointly held, used, or

UNDRIP Article 22(2):
"States shall take measures,
in conjunction with
indigenous peoples, to ensure
that indigenous women
and children enjoy the full
protection and guarantees
against all forms of violence
and discrimination."

UNDRIP Article 22(2): 
possessed property to be disposed of.

7. Recognize customary and religious marriage as legally valid: Recognize customary and religious marriages as legally valid, regardless of whether a dowry or bride-price payment has been exchanged. Where the payment of bride price or dowry is legal, forbid a spouse or any other person from requiring the repayment/return of dowry or bride price upon divorce or the death of a spouse. If the law requires that customary marriages be registered, such requirements should be minimal, such that indigenous and rural women can register their marriages in a simple and affordable manner.

8. Recognize the validity of unmarried consensual unions: Formally recognize and define unmarried consensual unions as a family unit and recognize that partners within consensual unions possess the same inheritance rights as married partners.

9. Recognize all women's equal rights to intestate inheritance: With respect to all inheritance frameworks practiced in a country, pass overarching succession laws recognizing the intestate inheritance rights of widows, women in consensual unions, and daughters at a level equal to their respective male counterparts.

10. Prohibit customary and religious courts from discriminating against women's inheritance rights: Require all decisions by customary/religious courts regarding inheritance to refrain from discriminating against the rights of women and children, and to adhere to the constitution.

\section{Growing Momentum and Opportunities for Securing Indigenous and Rural Women's Tenure Rights}

Both the passage and implementation of laws recognizing women's community-based tenure rights require coordinated efforts across multiple sectors that are tailored to communities' realities and reflective of the advocacy objectives and priorities of indigenous and rural women. The road to fully respecting women's rights in law and in practice is long, but local, national, and global commitments to improve and uphold women's tenure rights are only growing. History and research show that when women are accorded equal rights to access, use, and govern forests and other lands, women, communities and larger society benefit in a myriad of ways. Now more than ever before, opportunities abound to uphold indigenous and rural women's rights to equal treatment and equal opportunity, while better valuing and supporting the vast contributions that they make to their communities and to the stewardship of lands and natural resources.

This brief was authored by Stephanie Keene and Chloe Ginsburg, with important contributions from Andy White, Alain Frechette, and Solange Bandiaky-Badji. The authors extend special appreciation to Jonas Dahlstrom, David Gritten, Luisa Rios Romero, Brigadier Siachitema, and Liz Alden Wiley, who made significant contributions to this analysis. 


\section{Endnotes}

' The terms "community," "community lands," "community forests," and "community-based tenure" as utilized in this brief are defined in Section 2.2 of Power and Potential: A Comparative Analysis of National Laws and Regulations concerning Women's Rights to Community Forests. "Community lands" and "community forests" are "lands or forests subject to community-based tenure." "Community-based tenure" denotes "situations in which the right to own or manage terrestrial natural resources is held at the community level" by Indigenous Peoples and local communities. Rights and Resources Initiative (RRI). 2017. Power and Potential: A Comparative Analysis of National Laws and Regulations concerning Women's Rights to Community Forests. Section 2.2. Rights and Resources Initiative, Washington DC, p. 14. Available at: http://rightsandresources.org/wp-content/uploads/2017/07/Power-and-Potential-A-Comparative-Analysisof-National-Laws-and-Regulations-Concerning-Womens-Rights-to-Community-Forests_May-2017_RRI-1.pdf.

ii Rights and Resources Initiative (RRI). 2017. Power and Potential: A Comparative Analysis of National Laws and Regulations concerning Women's Rights to Community Forests. Rights and Resources Initiative, Washington DC, p. 14. Available at: http://rightsandresources.org/wp-content/uploads/2017/07/Power-and-Potential-A-Comparative-Analysisof-National-Laws-and-Regulations-Concerning-Womens-Rights-to-Community-Forests_May-2017_RRI-1.pdf

iii Power and Potential, p.14 (endnote 1).

iv Ibid.

${ }^{\vee}$ Rights and Resources Initiative (RRI). 2017. Securing Community Land Rights: Priorities and Opportunities to Advance Climate and Sustainable Development Goals, p. 1. Rights and Resources Initiative, Washington DC. Available at: http:// rightsandresources.org/wp-content/uploads/2017/09/Stockholm-Prorities-and-Opportunities-Brief.pdf, citing Who Owns the World's Land? (RRI, 2015).

vi Power and Potential, p. 47.

vii Power and Potential, p. 37. The Convention on the Elimination of All Forms of Discrimination against Women (CEDAW) was adopted by the UN General Assembly in 1979. It is a binding source of international law that is often considered to be the international bill of rights for women. It defines discrimination against women and establishes a strategy and related obligations for national governments to end all forms of such discrimination. Relatedly, the Committee on the Elimination of All Forms of Discrimination against Women is a body of independent experts that monitors the implementation of the CEDAW Convention and makes recommendations to State Parties concerning issues impacting women that State Parties should address. These recommendations often provide more specific interpretations of the CEDAW Convention's articles, and are published in the Committee's General Recommendations.

viii Ibid. at p. 38.

ix Securing Community Land Rights: Priorities and Opportunities to Advance Climate and Sustainable Development Goals, p. 1 (RRI, 2017), citing Who Owns the World's Land? (RRI, 2015).

$\times$ Ibid. at p. 8.

${ }^{x i}$ Community-based tenure regimes (CBTRs) are national-level legal frameworks that recognize community-based tenure systems. They are the primary unit of analysis in Power and Potential and are defined as "a distinguishable set of national, state-issued laws and regulations governing 'all situations under which the right to own or manage terrestrial natural resources is held at the community level."' Power and Potential, p. 16 (endnote 1).

xii Power and Potential, p. 48.

xiii Ibid. at p. 9.

xiv Food and Agriculture Organization (2013). Governing land for women and men: A technical guide to support the 
rightsandresources.org

achievement of responsible gender-equitable governance of land tenure, pp. 28-29. Food and Agriculture Organization, Rome, Italy. Available at: http://www.fao.org/3/a-i3114e.pdf.

xv Power and Potential, p. 17.

xvi This section includes legislative best practices identified in land and forest laws, community land and forest laws, laws recognizing Indigenous Peoples' and local communities' customs and governance institutions, and laws on rural land development. 


\section{The Rights and Resources Initiative}

RRI is a global coalition consisting of 15 Partners, 7 Affiliated Networks, 14 International Fellows, and more than 150 collaborating international, regional, and community organizations dedicated to advancing the forestland and resource rights of Indigenous Peoples and local communities. RRI leverages the capacity and expertise of coalition members to promote secure local land and resource rights and catalyze progressive policy and market reforms.

RRI is coordinated by the Rights and Resources Group, a non-profit organization based in Washington, DC. For more information, please visit www.rightsandresources.org.

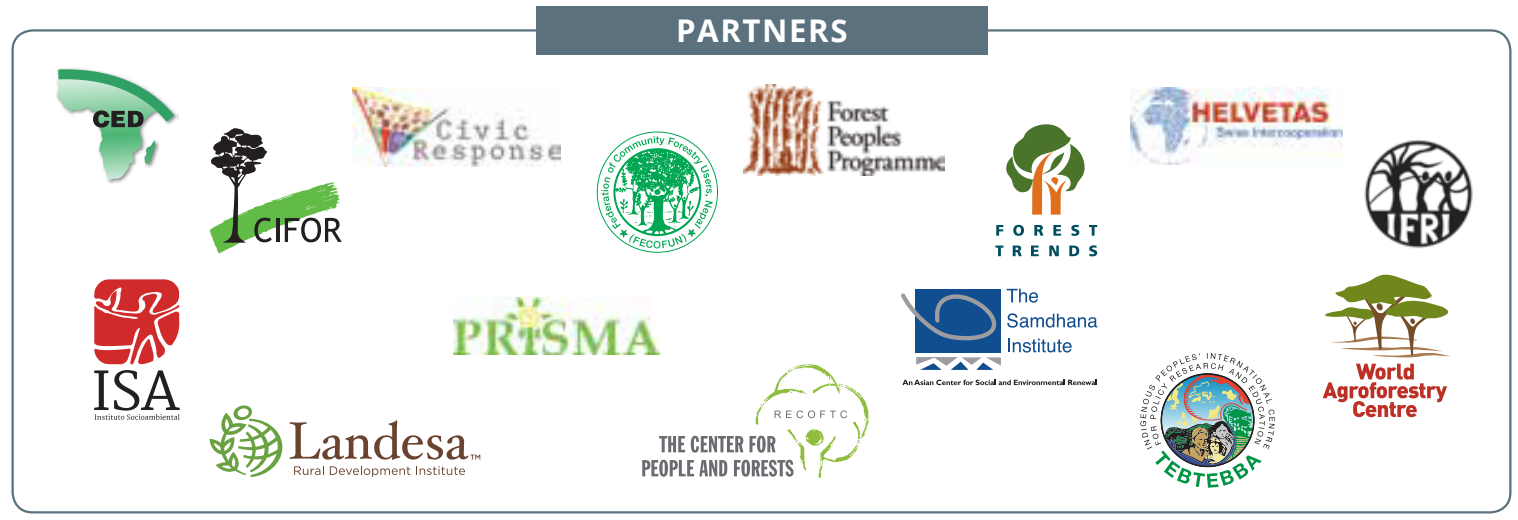

\section{AFFILIATED NETWORKS}

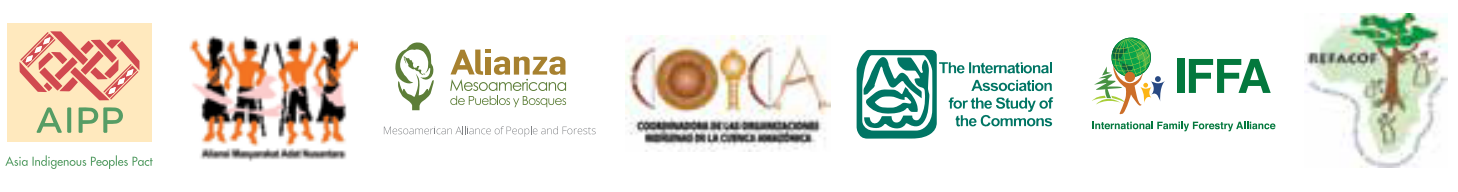

SUPPORTERS

$N$ L

TIM

UKaid

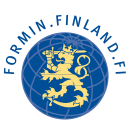

MINISTRY FOR FOREIGN AFFAIRS OF FINLAND

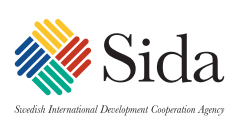

FORDFOUNDATION

The views presented here are not necessarily shared by the agencies that have generously supported this work.

This work is licensed under a Creative Commons Attribution License CC BY 4.0.

Rights and Resources Initiative

Washington, DC

Copyright (C 2018 Rights and Resources Initiative

Reproduction permitted with attribution

ISBN 978-0-692-89531-3 


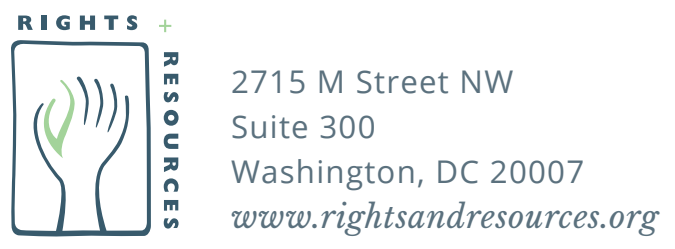

